\title{
Renin-Angiotensin System Inhibition in Conscious Dogs during Acute Hypoxemia
}

\author{
EFFECTS ON SYSTEMIC HEMODYNAMICS, REGIONAL \\ BLOOD FLOWS, AND TISSUE METABOLISM
}

\author{
Chang-Seng Liang and Haralambos Gavras, Departments of Medicine and \\ Pharmacology, and the Cardiovascular Institute, Boston University School of \\ Medicine, and the Cardiology and Hypertension Departments and Thorndike \\ Memorial Laboratory, Boston City Hospital, Boston, Massachusetts 02118
}

\begin{abstract}
A B S T RACT The role of the renin-angiotensin system in mediating the circulatory and metabolic responses to hypoxia was studied in three groups of conscious dogs that were infused continuously with normal saline, teprotide $(10 \mu \mathrm{g} / \mathrm{kg}$ per min), and saralasin $(1 \mu \mathrm{g} / \mathrm{kg}$ per min), respectively. Hypoxia was produced by switching from breathing room air to 5 or $8 \%$ oxygen-nitrogen mixture. Plasma renin activity increased from $2.3 \pm 0.4$ to $4.9 \pm 0.8 \mathrm{ng} / \mathrm{ml}$ per $\mathrm{h}$ during $8 \%$ oxygen breathing, and from $2.8 \pm 0.4$ to $8.4 \pm 1.8 \mathrm{ng} /$ $\mathrm{ml}$ per $\mathrm{h}$ during $5 \%$ oxygen breathing. As expected, cardiac output, heart rate, mean aortic blood pressure, and left ventricular $d P / d t$ and $d P / d t / P$ increased during both 5 and $8 \%$ oxygen breathing in the saline-treated dogs; greater increases occurred during the more severe hypoxia. Teprotide and saralasin infusion diminished the hemodynamic responses to $5 \%$ oxygen breathing, but did not affect the responses to $8 \%$ oxygen breathing significantly. In addition, the increased blood flows to the myocardium, kidneys, adrenals, brain, intercostal muscle, and diaphragm that usually occur during $5 \%$ oxygen breathing were reduced by both agents. These agents also reduced the increases in plasma norepinephrine concentration during 5\% oxygen breathing, but had no effects on tissue aerobic or anaerobic metabolism.

In dogs pretreated with propranolol and phentolamine, administration of teprotide $(0.5 \mathrm{mg} / \mathrm{kg})$ during
\end{abstract}

This study was presented in part at the 70th Annual Meeting of the American Society for Clinical Investigation, San Francisco, Calif., 1 May 1978.

Dr. Gavras is an American Heart Association Established Investigator.

Received for publication 27 February 1978 and in revised form 10 July 1978.
$5 \%$ oxygen breathing reduced mean aortic blood pressure and total peripheral vascular resistance, and increased cardiac output and heart rate, but did not affect left ventricular $d P / d t, d P / d t / P$, and end-diastolic pressure. Simultaneously, renal and myocardial blood flows increased and myocardial oxygen extraction decreased, while myocardial oxygen consumption did not change significantly.

These results suggest that the renin-angiotensin system plays an important role in the hemodynamic responses to severe hypoxia. It appears that angiotensin not only exerts a direct vasoconstrictor action, especially upon the coronary and renal circulations, but also potentiates the cardiovascular effects of sympathetic stimulation that occur during severe hypoxia.

\section{INTRODUCTION}

Increasing evidence has accumulated that hypoxia stimulates the renin-angiotensin system. Low oxygen tension increases the granularity of human juxtaglomerular cells cultured in vitro (1). Alveolar hypoxia in vivo also increases the number of granules of juxtaglomerular cells $(2,3)$, plasma renin activity $(4,5)$, plasma angiotensin II levels (6), and the angiotensin converting enzyme activity both in the lungs and in the serum (7). The mechanisms of renin release during hypoxia are not clearly elucidated. The increase in the granularity of juxtaglomerular cells (1-3) would suggest a direct action of hypoxia on renin release, but acute local renal perfusion with hypoxic blood did not increase the renin activity in renal venous blood (8). On the other hand, renin may be released by sympathetic discharge (9) produced by hypoxia. Furthermore, renal blood flow may decrease during severe hypoxia and this can also cause renin release (9). The magnitude 
of the renin-angiotensin response to hypoxia may also be related to the degree of hypoxia and the underlying state of activation of the renin-angiotensin system (6).

In this paper, we studied the physiologic importance of the renin-angiotensin system in mediating the cardiovascular responses to both moderate and severe hypoxia by pretreating animals with teprotide (SQ 20,881 ), an angiotensin converting enzyme inhibitor (10), and saralasin (1-sarcosine-8-alanine-angiotensin II), an angiotensin-receptor blocking agent (11). Regional blood flows and anaerobic tissue metabolism were also studied. We have recently found that administration of teprotide increases blood flow to the myocardium, kidneys, and brain in conscious dogs during salt depletion $(12,13)$. This suggests that these organs are particularly susceptible to the vasoconstrictor action of angiotensin II.

Because angiotensin could have a significant action on the sympathetic nervous system (14), it may exert its hemodynamic effects indirectly by increasing catecholamine release. To study the possible contribution of the sympathetic nervous system during hypoxia, we measured plasma norepinephrine levels in dogs with and without the renin-angiotensin system inhibition. In addition, we administered teprotide into dogs during hypoxia after they had been pretreated with $\alpha$ and $\beta$-adrenergic receptor blocking agents to study the direct effects of angiotensin on the cardiovascular system during hypoxia.

\section{METHODS}

Adult male beagle dogs, weighing between 6.8 and $16.8 \mathrm{~kg}$, were sedated with morphine sulfate $(1 \mathrm{mg} / \mathrm{kg})$. The trachea was cannulated with a T tube, by local lidocaine (Xylocaine) anesthesia. The aorta and the coronary sinus were cannulated with French 8 Cournand catheters, and the pulmonary artery was cannulated with a French 7 Swan-Ganz catheter (Edwards Laboratories, Inc., Santa Ana, Calif.). The aortic catheter was introduced via a femoral artery. Both coronary sinus and Swan-Ganz catheters were inserted under fluoroscopic guidance via external jugular veins. All catheters were connected to Statham P23Db pressure transducers (Statham Instruments, Inc., Oxnard, Calif.), whose signals were fed into a multichannel Brush 480 recorder (Gould, Inc., Instrument Systems Division, Cleveland, Ohio) to measure blood pressures and heart rate.

The left ventricle was cannulated via the left carotid artery with a Millar transducer-tip catheter (Millar Instruments, Inc., Houston, Tex.) for measuring left ventricular end-diastolic and systolic pressures, and the first derivative of left ventricular pressure $(d P / d t)$. The ratio of $d P / d t$ to a developed left ventricular pressure of $50 \mathrm{~mm} \mathrm{Hg}$ was calculated for 10 consecutive cardiac cycles at each measurement period, with a PDP-11/10 minicomputer (Digital Equipment Corp., Maynard, Mass.). This pressure occurred during isovolumic systole; this ratio is referred to as $d P / d t / P(15)$.

Cardiac output was determined by an indocyanine green (Cardio-Green) dye dilution technique, with a Gilford model 140 cardiac output system (Gilford Instrument Laboratories Inc., Oberlin, Ohio). Regional blood flows were determined by a modification (16) of the radioactive microsphere method of Rudolph and Heymann (17). 450,000 microspheres, 15 \pm 3 $\mu \mathrm{m}$ in diameter, and labeled with cerium-141, tin-113, strontium-85, or scandium- 46 at a sp act of $10 \mathrm{mCi} / \mathrm{g}$, were injected into the left ventricle via the Millar catheter, which was immediately flushed with $10 \mathrm{ml}$ of normal saline over a 30-s period. Arterial reference blood was withdrawn with a Harvard pump (Harvard Apparatus Co., Inc., Millis, Mass.) at a rate of $7.75 \mathrm{ml} / \mathrm{min}$, beginning $10 \mathrm{~s}$ before the injection of microspheres and continuing for $80 \mathrm{~s}$ thereafter. The content of radioactivity in each organ was measured in a Packard gamma spectrometer with a model 9012 multichannel analyzer (Packard Instrument Co., Inc., Downers Grove, Ill.) at the appropriate gamma photon energy for each of the radionuclides. Absolute blood flow to each organ was calculated by the reference sample method on a PDP-11/10 minicomputer (16). Mean aortic blood pressure was divided by cardiac output or organ blood flow to yield the total peripheral or regional organ vascular resistance.

Arterial and coronary sinus venous blood samples were obtained to measure $\mathrm{pH}, \mathrm{PO}_{2}$ and $\mathrm{PCO}_{2}$ on a Radiometer PHM71 acid base analyzer (Radiometer Co., Copenhagen, Denmark), and to measure oxygen content by gas chromatography (18). Blood oxygen capacity was measured by a cyanmethemoglobin method (19). Plasma renin activity (20) and norepinephrine concentration (21) were determined by radioimmunoassay and radioenzymatic methods, respectively. Arterial and coronary blood samples were taken immediately after microsphere injections for measuring lactate (22), pyruvate (23), $\beta$-hydroxybutyrate (24), and acetoacetate (25). Myocardial oxygen consumption, left ventricular work, total body oxygen consumption, and myocardial utilization rates of lactate and pyruvate were calculated by conventional formulas.

21 animals were divided equally into three groups. They were infused continuously with normal saline, teprotide, or saralasin at a rate of $0.229 \mathrm{ml} / \mathrm{min}$, delivered by a Harvard infusion pump (Harvard Apparatus Co., Inc.). Teprotide and saralasin were dissolved in normal saline in concentrations which permitted delivery of $10 \mu \mathrm{g} / \mathrm{kg}$ per min and $1 \mu \mathrm{g} / \mathrm{kg}$ per $\mathrm{min}$, respectively. The protocol involved an initial 20 - $\mathrm{min}$ control period, a 20-min period of hypoxia, a 40-min recovery period, a second 20-min control period, a second $20-\mathrm{min}$ period of hypoxia, and a final recovery period. The normal saline or drug infusion continued throughout the experiment, and each dog received only one kind of infusion. Two different degrees of hypoxia were produced in each dog during the two hypoxic periods by switching from breathing room air to 8 or $5 \%$ oxygen-nitrogen mixture. The sequence of these two degrees of hypoxia varied in random order from dog to dog. Systemic hemodynamic measurements were obtained at 5min intervals during both control and hypoxic periods. Averages were obtained from triplicate measurements of each hemodynamic variable during the control period. These values from each dog were then averaged and are reported as prehypoxic control values in Results. Circulating tissue metabolites, plasma renin activity, plasma norepinephrine, and organ blood flows were determined immediately before hypoxia and after $20 \mathrm{~min}$ of hypoxia, $1 \mu \mathrm{g}$ [1-Asp, 5-Ile]angiotensin I (Schwartz/Mann Div., Becton, Dickinson and Company, Orangeburg, N. Y.) and $1 \mu \mathrm{g}$ [1-Asp, 5-Ile]angiotensin II (Sigma Chemical Co., St. Louis, Mo.) were administered intravenously, before the start of the normal saline or drug infusion and again during the recovery periods after hypoxia, to ascertain whether pharmacologic blockade had been produced by teprotide and saralasin.

Another 23 dogs, also divided into three groups, were pretreated intravenously with propranolol $(0.3 \mathrm{mg} / \mathrm{kg})$ and 
phentolamine $(5 \mathrm{mg} / \mathrm{kg})$. Degrees of $\alpha$ - and $\beta$-adrenergic receptor blockade were determined, before and after drug treatments, by measuring aortic blood pressure and heart rate responses to norepinephrine and isoproterenol, respectively. Two groups of the dogs were made hypoxic with $5 \%$ oxygen breathing for $20 \mathrm{~min}$ and after $10 \mathrm{~min}$ of hypoxia, either teprotide $(0.5 \mathrm{mg} / \mathrm{kg})$ or normal saline $(2 \mathrm{ml})$ was injected. The same does of teprotide was administered to the third group that breathed room air. Systemic hemodynamic measurements were also obtained every $5 \mathrm{~min}$. Regional blood flows and metabolites were measured during the control period, and at $10 \mathrm{~min}$ and $20 \mathrm{~min}$ of hypoxia. Angiotensin I $(1 \mu \mathrm{g})$ was administered intravenously at the beginning and end of the experiment to determine angiotensin converting enzyme inhibition.

The data for each degree of hypoxia were treated statistically with two-way analysis of variance for independent groups with trend analysis (26), and the significance of the differences between control and experimental values was determined by Dunnett's test (27). The difference was considered significant if $P<0.05$. Student's $t$ test for paired comparisons was used to determine the statistical significance of a difference between two means in the same group of animals. Values are mean $\pm \mathrm{SE}$.

\section{RESULTS}

Effects of alveolar hypoxia on arterial blood gases and plasma renin activity. Acute alveolar hypoxia decreased arterial blood $\mathrm{PO}_{2}$ and $\mathrm{PCO}_{2}$, and increased arterial blood $\mathrm{pH}$ and plasma renin activity. The magnitude of changes was similar in all three groups of dogs treated with normal saline $(11.1 \pm 1.0 \mathrm{~kg})$, teprotide $(11.9 \pm 1.2 \mathrm{~kg})$, and saralasin $(12.2 \pm 1.0 \mathrm{~kg})$, and the results were pooled for statistical analysis (Table I). As expected, the more severe hypoxia produced greater changes in these parameters.

Effects of teprotide and saralasin on pressor responses to angiotensin I and II. Angiotensin $\mathrm{I}(1 \mu \mathrm{g})$ was injected intravenously before administration of teprotide, and again during teprotide infusion when the

TABLE I

Effects of $8 \%$ and $5 \%$ Oxygen Breathing on Arterial Blood Gases and Plasma Renin Activity

\begin{tabular}{|c|c|c|c|c|}
\hline & \multicolumn{3}{|c|}{ Arterial blood } & \multirow{2}{*}{$\begin{array}{l}\text { Plasma } \\
\text { renin } \\
\text { activity }\end{array}$} \\
\hline & $\mathrm{PO}_{2}$ & $\mathrm{PCO}_{2}$ & $\mathrm{pH}$ & \\
\hline $\begin{array}{l}8 \% \text { Oxygen } \\
\text { breathing }\end{array}$ & $m m \mathrm{Hg}$ & $m m \mathrm{Hg}$ & & $n g / m l / h$ \\
\hline Control & $86 \pm 2$ & $43 \pm 1$ & $7.38 \pm 0.01$ & $2.3 \pm 0.4$ \\
\hline $\begin{array}{l}\text { Hypoxia } \\
\text { 5\% Oxygen } \\
\text { breathing }\end{array}$ & $31 \pm 1^{*}$ & $28 \pm 2 *$ & $7.52 \pm 0.01^{*}$ & $4.9 \pm 0.8^{*}$ \\
\hline Control & $84 \pm 2$ & $42 \pm 1$ & $7.39 \pm 0.01$ & $2.8 \pm 0.4$ \\
\hline Hypoxia & $23 \pm 1^{*}$ & $21 \pm 1^{*}$ & $7.58 \pm 0.01 *$ & $8.4 \pm 1.8^{*}$ \\
\hline
\end{tabular}

Values are mean $\pm \mathrm{SE} ; n=21$ in each group.

* Indicates values that are significantly different from the prehypoxic control at $P<0.05$. hemodynamic measurements had returned to baseline values, after 8 and 5\% oxygen breathing. Mean aortic blood pressure in response to angiotensin $I$ increased $20 \pm 4 \mathrm{~mm} \mathrm{Hg}$ before teprotide administration, but increased only $5 \pm 1$ and $8 \pm 2 \mathrm{~mm} \mathrm{Hg}$ after 8 and $5 \%$ oxygen breathing, respectively. Similar administration of angiotensin II increased mean aortic blood pressure $36 \pm 3 \mathrm{~mm} \mathrm{Hg}$ before saralasin administration, but, during saralasin infusion, only $3 \pm 1$ and $1 \pm 1 \mathrm{~mm} \mathrm{Hg}$ after 8 and $5 \%$ oxygen breathing, respectively. These decreases in pressor responses to angiotensin I and II after administration of teprotide and saralasin, respectively, were significant at $P<0.001$, as determined by Student's $t$ test for paired comparisons.

Angiotensin I and II were also administered to the saline-treated animals. At the beginning of the experiment, angiotensin I and II increased mean aortic blood pressure $18 \pm 3$ and $31 \pm 2 \mathrm{~mm} \mathrm{Hg}$, respectively, and at the end of the experiment $17 \pm 1$ and $30 \pm 2 \mathrm{~mm} \mathrm{Hg}$, respectively. There were no significant differences between the pressor responses to angiotensin at the beginning and end of the experiment.

Effects of teprotide and saralasin on changes in systemic hemodynamics and regional blood flow during hypoxia. Alveolar hypoxia increased cardiac output, heart rate, mean aortic blood pressure, left ventricular $d P / d t$ and $d P / d t / P$, and decreased total peripheral vascular resistance. In the saline group, severe hypoxia with $5 \%$ oxygen breathing produced greater hemodynamic changes than moderate hypoxia with $8 \%$ oxygen breathing (Fig. 1). The control values before hypoxia were similar before 8 and $5 \%$ oxygen breathing in this group. Similar values were found in the prehypoxic periods in the teprotide and saralasin groups. Fig. 2 shows the percent change (from the control value) during hypoxia, in each hemodynamic variable for all three experimental groups. The magnitude of the responses to a given degree of hypoxia was similar in each experimental group, regardless of the sequence of administering the 5 and $8 \%$ oxygen-nitrogen mixtures. Neither teprotide nor saralasin significantly altered the hemodynamic responses to $8 \%$ oxygen breathing, but both agents reduced the increases in cardiac output, heart rate, mean aortic blood pressure, left ventricular $d P / d t$, and $d P / d t / P$ that occurred during 5\% oxygen breathing. Changes in total peripheral vascular resistance, however, did not differ among the groups. In addition, left ventricular end-diastolic pressure decreased in the saline group from $9.0 \pm 1.2$ to $6.6 \pm 1.1$, and from $9.1 \pm 1.3$ to $4.7 \pm 0.8 \mathrm{~mm} \mathrm{Hg}$ during 8 and $5 \%$ oxygen breathing, respectively. Similar decreases during 8 and $5 \%$ oxygen breathing were found in the teprotide $(-3.0 \pm 1.0$ and $-2.2 \pm 0.9 \mathrm{~mm} \mathrm{Hg}$, respectively) and saralasin $(-2.7 \pm 0.8$ and $-2.2 \pm 1.0$ $\mathrm{mm} \mathrm{Hg}$, respectively) groups.

Table II shows the percent changes in regional blood 


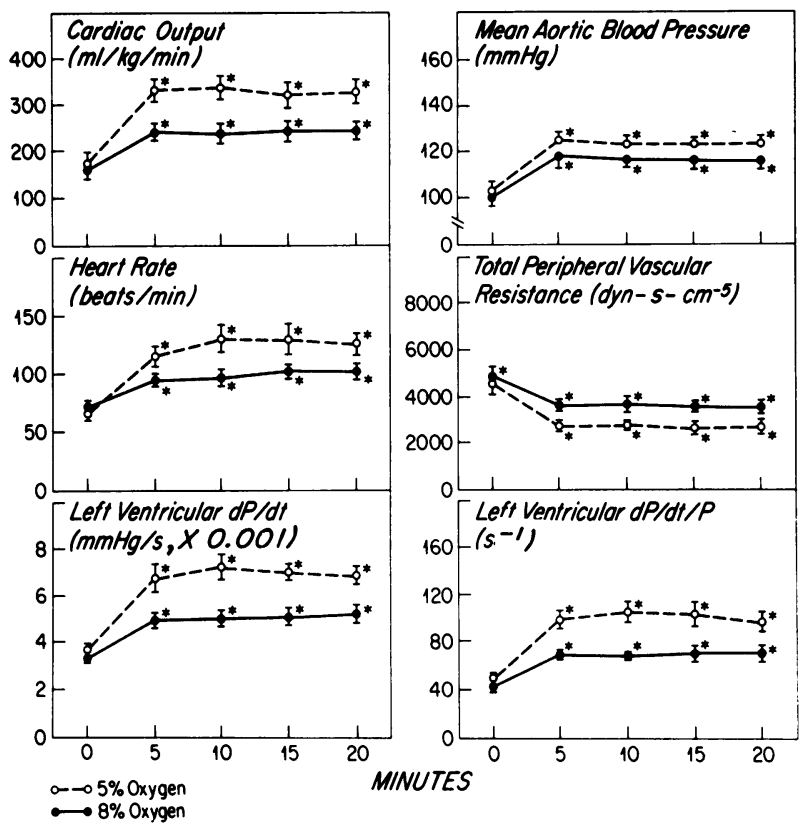

FIGURE 1 Changes in cardiac output, heart rate, mean aortic blood pressure, total peripheral vascular resistance, left ventricular $d P / d t$, and $d P / d t / P$ in seven saline-treated conscious dogs during 8\% (closed circles) and 5\% (open circles) oxygen breathing. Bars show SE. Asterisks indicate values that are statistically different from the prehypoxic values at $P<0.05$, as determined by Dunnett's test (27).

flows during hypoxia in the saline-, teprotide-, and saralasin-treated animals; the prehypoxic values did not differ among the groups. In the saline group, blood flow increased to the right and left ventricles, adrenal glands, diaphragm, and intercostal muscle during $8 \%$ oxygen breathing. Blood flow also increased to the brain, kidneys, liver, and femoral muscle during $5 \%$ oxygen breathing. Blood flow to lungs, stomach, small and large intestines, skin, and bone, however, did not change significantly during either gas breathing. Table II also shows that blood flow responses to $8 \%$ oxygen breathing in the teprotide and saralasin groups were like those in the saline group, but the increases in blood flows to the ventricles, kidneys, adrenals, brain, intercostal muscle, and diaphragm that occur during 5\% oxygen breathing were reduced by teprotide and saralasin.

Effects of teprotide and saralasin on changes in plasma norepinephrine concentration during hypoxia. Plasma norepinephrine concentration did not change significantly during $8 \%$ oxygen breathing in the saline-, teprotide-, and saralasin-treated dogs (Table III). In contrast, it increased significantly during $5 \%$ oxygen breathing. Its increases, however, were significantly smaller in the teprotide and saralasin groups than in the saline group.

Effects of teprotide and saralasin on changes in cardiac metabolism and energetics during hypoxia. Table IV shows the changes in myocardial oxygen consumption, left ventricular work, myocardial oxygen extraction, and myocardial utilization rates of lactate and pyruvate that occurred during 8 and $5 \%$ oxygen breathing in the saline-, teprotide-, and saralasintreated dogs. The prehypoxic control values of these variables in the saline-treated dogs were $500 \pm 98 \mu \mathrm{mol} /$ $100 \mathrm{~g}$ per $\min , 6.8 \pm 0.7 \mathrm{~kg} \cdot \mathrm{m} / 100 \mathrm{~g}$ per $\min , 78 \pm 4 \%$, $87 \pm 20 \mu \mathrm{mol} / 100 \mathrm{~g}$ per min, and $17 \pm 4 \mu \mathrm{mol} / 100 \mathrm{~g}$ per min, respectively. Similar control values were found in the teprotide- and saralasin-treated dogs.

Alveolar hypoxia increased myocardial oxygen consumption, left ventricular work, and myocardial utilization of lactate and pyruvate in the saline-treated animals. These changes were more marked during 5\% oxygen breathing than $8 \%$ oxygen breathing. Myocardial oxygen extraction, however, did not change at either level of hypoxia.

Infusion of teprotide and saralasin did not modify the cardiac metabolic responses to $8 \%$ oxygen breathing, but did reduce the increases in myocardial oxygen consumption, left ventricular work, and myocardial utilization of lactate and pyruvate that occurred during $5 \%$ oxygen breathing.

Effects of teprotide and saralasin on changes in total body oxygen consumption and anaerobic tissue

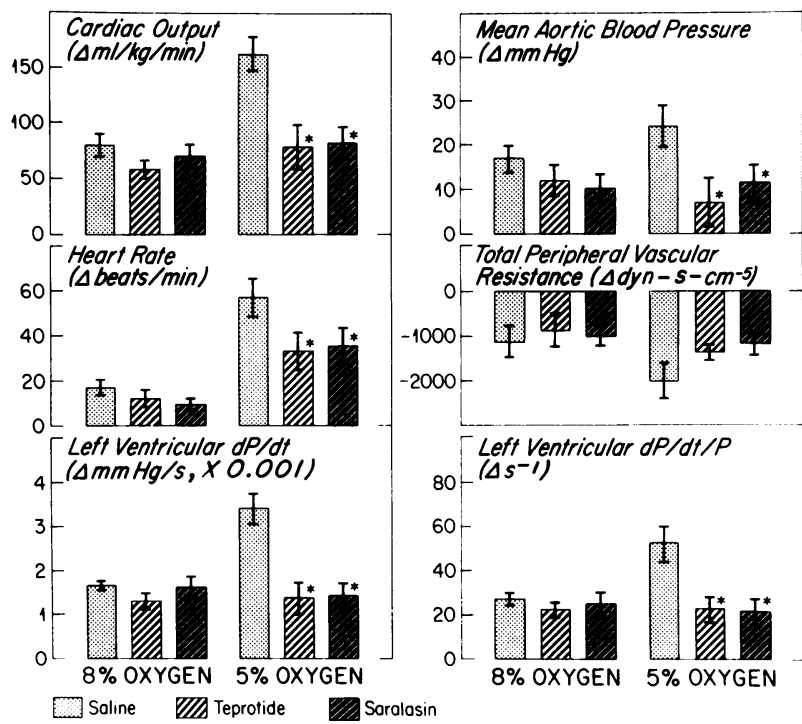

FIGURE 2 Changes in cardiac output, heart rate, mean aortic blood pressure, total peripheral vascular resistance, left ventricular $d P / d t$, and $d P / d t / P$ during $8 \%$ and $5 \%$ oxygen breathing in the saline-, teprotide-, and saralasin-treated dogs ( $n=7$ in each group). The changes were based on the average values of repetitive measurements made at 5 -min intervals during the 20-min hypoxic period. Bars show SE. Asterisks indicate values that are statistically different from those in the saline-treated dogs at $P<0.05$, as determined by Dunnett's test (27). 


\section{TABLE II}

Percent Changes in Organ Blood Flows during Hypoxia in Saline-, Teprotide-, and Saralasin-Treated Animals

\begin{tabular}{|c|c|c|c|c|c|c|}
\hline \multirow[b]{2}{*}{ Organ } & \multicolumn{3}{|c|}{$8 \%$ Oxygen breathing } & \multicolumn{3}{|c|}{$5 \%$ Oxygen breathing } \\
\hline & Saline & Teprotide & Saralasin & Saline & Teprotide & Saralasin \\
\hline Right ventricle & $133 \pm 27^{*}$ & $97 \pm 26^{*}$ & $71 \pm 15^{*}$ & $636 \pm 114^{*}$ & $148 \pm 25^{*} \ddagger$ & $167 \pm 32 * t$ \\
\hline Left ventricle & $96 \pm 20^{*}$ & $98 \pm 21 *$ & $81 \pm 16^{*}$ & $690 \pm 170^{*}$ & $194 \pm 30^{*} \ddagger$ & $200 \pm 34 * t$ \\
\hline Kidneys & $24 \pm 18$ & $7 \pm 7$ & $-6 \pm 5$ & $77 \pm 29 *$ & $-10 \pm 6 \ddagger$ & $2 \pm 7 \ddagger$ \\
\hline Adrenals & $100 \pm 24^{*}$ & $51 \pm 10^{*}$ & $42 \pm 16^{*}$ & $276 \pm 70^{*}$ & $51 \pm 14^{*} t$ & $63 \pm 10^{*} t$ \\
\hline Brain & $52 \pm 28$ & $26 \pm 14$ & $51 \pm 20$ & $341 \pm 88^{*}$ & $94 \pm 25^{*} \ddagger$ & $138 \pm 31 * t$ \\
\hline Lungs (bronchial) & $-3 \pm 24$ & $16 \pm 18$ & $5 \pm 14$ & $137 \pm 76$ & $75 \pm 39$ & $55 \pm 26$ \\
\hline Liver (hepatic) & $26 \pm 19$ & $20 \pm 24$ & $10 \pm 19$ & $79 \pm 18 *$ & $79 \pm 13^{*}$ & $113 \pm 25^{*}$ \\
\hline Stomach & $23 \pm 13$ & $17 \pm 24$ & $-28 \pm 15$ & $61 \pm 30$ & $-15 \pm 14$ & $54 \pm 27$ \\
\hline Small intestine & $21 \pm 8$ & $-15 \pm 20$ & $-17 \pm 9$ & $35 \pm 33$ & $-11 \pm 8$ & $0 \pm 7$ \\
\hline Large intestine & $-9 \pm 13$ & $-11 \pm 8$ & $-11 \pm 9$ & $21 \pm 29$ & $15 \pm 8$ & $10 \pm 16$ \\
\hline Skin & $25 \pm 17$ & $5 \pm 21$ & $-10 \pm 12$ & $-14 \pm 30$ & $-14 \pm 11$ & $18 \pm 16$ \\
\hline Femur & $16 \pm 16$ & $-6 \pm 15$ & $-11 \pm 10$ & $22 \pm 37$ & $-21 \pm 16$ & $-10 \pm 5$ \\
\hline \multicolumn{7}{|l|}{ Muscle } \\
\hline Femoral & $48 \pm 19$ & $44 \pm 23$ & $21 \pm 24$ & $184 \pm 33^{*}$ & $87 \pm 31^{*}$ & $70 \pm 28^{*}$ \\
\hline Intercostal & $90 \pm 31^{*}$ & $88 \pm 28 *$ & $81 \pm 22 *$ & $373 \pm 39 *$ & $172 \pm 37^{*} \ddagger$ & $171 \pm 28 * t$ \\
\hline Diaphragm & $110 \pm 28^{*}$ & $98 \pm 35^{*}$ & $69 \pm 19^{*}$ & $947 \pm 222^{*}$ & $338 \pm 84^{*} \ddagger$ & $387 \pm 77 * t$ \\
\hline
\end{tabular}

Values are percent changes from the control in mean $\pm S E ; n=7$ in each group.

* Indicates changes that are significantly different from the prehypoxic control at $P<0.05$.

I Indicates that the value is different from that in the saline-treated dogs at $P<0.05$, as determined by Dunnett's test (27).

metabolism during hypoxia. Table $\mathrm{V}$ shows the hypoxic changes in total body oxygen consumption, arterial lactate concentration, and lactate:pyruvate and $\beta$-hydroxybutyrate:acetoacetate ratios in the saline-, teprotide-, and saralasin-treated dogs. The prehypoxic control values of these variables were $8.3 \pm 0.5 \mathrm{ml} / \mathrm{kg}$ per min, $2.0 \pm 0.2 \mathrm{mM}, 6.7 \pm 0.4$, and $1.1 \pm 0.1$, respectively, in the saline group; the other two groups had similar control values. Total body oxygen consumption did not change during either 8 or $5 \%$ oxygen breathing in any of these three groups. Arterial lactate concentration, lactate:pyruvate ratio, and $\beta$-hydroxybutyrate: acetoacetate ratio, however, increased, and were larger during $5 \%$ oxygen breathing than $8 \%$ oxygen breathing. These increases also did not differ among the three groups.

Effects of teprotide on hemodynamic responses to $5 \%$ oxygen breathing in propranolol- and phentolamine-pretreated dogs. Propranolol and phentolamine pretreatment reduced heart rate and pressor responses to isoproterenol and norepinephrine, respectively. The dose of isoproterenol required to accelerate heart rate 25 beats/min increased from $1.5 \pm 0.3 \mu \mathrm{g}$ before to $21 \pm 2$ $\mu \mathrm{g}$ after pretreatment $(P<0.001)$, and the dose of norepinephrine required to raise arterial blood pressure $25 \mathrm{~mm} \mathrm{Hg}$ increased from $4.6 \pm 0.3$ to $57 \pm 6 \mu \mathrm{g}$

TABLE III

Effects of Hypoxia on Plasma Concentration of Norepinephrine

\begin{tabular}{|c|c|c|c|c|c|c|}
\hline \multirow[b]{2}{*}{ Group } & \multicolumn{3}{|c|}{$8 \%$ Oxygen breathing } & \multicolumn{3}{|c|}{$5 \%$ Oxygen breathing } \\
\hline & Control & Hypoxia & Change & Control & Hypoxia & Change \\
\hline & \multicolumn{3}{|c|}{$n g / m l$} & \multicolumn{3}{|c|}{$n g / m l$} \\
\hline Saline & $0.17 \pm 0.03$ & $0.42 \pm 0.16$ & $0.25 \pm 0.13$ & $0.23 \pm 0.05$ & $0.90 \pm 0.22^{*}$ & $0.67 \pm 0.14$ \\
\hline Teprotide & $0.31 \pm 0.06$ & $0.44 \pm 0.16$ & $0.13 \pm 0.06$ & $0.31 \pm 0.06$ & $0.63 \pm 0.13^{*}$ & $0.32 \pm 0.08 \ddagger$ \\
\hline Saralasin & $0.22 \pm 0.04$ & $0.34 \pm 0.09$ & $0.12 \pm 0.08$ & $0.27 \pm 0.06$ & $0.57 \pm 0.11^{*}$ & $0.29 \pm 0.09 \ddagger$ \\
\hline
\end{tabular}

Values are mean $\pm \mathrm{SE} ; n=7$ in each group.

* Indicates values that are significantly different from the prehypoxic values at $P<0.05$.

$\$$ Indicates that the hypoxic change is significantly different from that in the saline-treated dogs at $P<0.05$, as determined by Dunnett's test (27). 
TABLE IV

Changes in Cardiac Metabolism and Energetics during Hypoxia in Saline-, Teprotide-, and Saralasin-Treated Animals

\begin{tabular}{|c|c|c|c|c|c|}
\hline \multirow[b]{2}{*}{ Group } & \multirow{2}{*}{$\begin{array}{l}\text { Myocardial } \\
\text { oxygen } \\
\text { consumption }\end{array}$} & \multirow{2}{*}{$\begin{array}{l}\text { Left } \\
\text { ventricular } \\
\text { work }\end{array}$} & \multirow{2}{*}{$\begin{array}{l}\text { Myocardial } \\
\text { oxygen } \\
\text { extraction }\end{array}$} & \multicolumn{2}{|c|}{ Myocardial utilization } \\
\hline & & & & Lactate & Pyruvate \\
\hline & $\mu \mathrm{mol} / 100 \mathrm{~g} / \mathrm{min}$ & $\mathrm{kg} \cdot \mathrm{m} / 100 \mathrm{~g} / \mathrm{min}$ & $\%$ & $\mu \mathrm{mol} / 1$ & $\mathrm{~g} / \min$ \\
\hline \multicolumn{6}{|c|}{$8 \%$ Oxygen breathing } \\
\hline Saline & $130 \pm 66$ & $4.4 \pm 0.5$ & $4 \pm 4$ & $38 \pm 10$ & $7 \pm 2$ \\
\hline Teprotide & $156 \pm 44$ & $2.6 \pm 0.3$ & $7 \pm 4$ & $35 \pm 8$ & $8 \pm 3$ \\
\hline Saralasin & $112 \pm 40$ & $3.9 \pm 1.1$ & $4 \pm 3$ & $40 \pm 11$ & $10 \pm 3$ \\
\hline \multicolumn{6}{|c|}{$5 \%$ Oxygen breathing } \\
\hline Saline & $420 \pm 73$ & $7.1 \pm 0.8$ & $2 \pm 4$ & $79 \pm 14$ & $24 \pm 4$ \\
\hline Teprotide & $89 \pm 44^{*}$ & $3.0 \pm 1.0 *$ & $-4 \pm 6$ & $36 \pm 6^{*}$ & $6 \pm 2 *$ \\
\hline Saralasin & $134 \pm 51^{*}$ & $4.0 \pm 0.7^{*}$ & $2 \pm 2$ & $43 \pm 8^{*}$ & $12 \pm 2 *$ \\
\hline
\end{tabular}

Values are changes from control values in mean $\pm \mathrm{SE} ; n=7$ in each group. All the changes produced by hypoxia, except those in myocardial oxygen extraction, are statistically significant at $P<0.05$.

* Indicates that the hypoxic change is significantly different from that in the saline-treated dogs at $P<0.05$, as determined by Dunnett's test (27).

$(P<0.001)$. 5\% oxygen breathing reduced arterial blood $\mathrm{PO}_{2}$ from $90 \pm 4$ to $21 \pm 1$ and $22 \pm 2 \mathrm{~mm} \mathrm{Hg}$, at 10 and $20 \mathrm{~min}$ of hypoxia, respectively. Cardiac output, heart rate, left ventricular $d P / d t$, and $d P / d t / P$ increased, and total peripheral vascular resistance decreased during hypoxia, but mean aortic blood pressure did not change significantly (Fig. 3). Administration of teprotide at $10 \mathrm{~min}$ of hypoxia in nine dogs $(10.9 \pm 0.7$

\section{TABLE V}

Changes in Aerobic and Anaerobic Metabolism during Hypoxia in Saline-, Teprotide-, and Saralasin-Treated Animals

\begin{tabular}{|c|c|c|c|c|}
\hline Group & $\begin{array}{c}\text { Total body } \\
\text { oxygen } \\
\text { consumption }\end{array}$ & $\begin{array}{l}\text { Arterial } \\
\text { lactate } \\
\text { concen- } \\
\text { tration }\end{array}$ & $\begin{array}{l}\text { Lactate: } \\
\text { pyruvate }\end{array}$ & $\begin{array}{l}\text { } \beta \text {-Hydroxy- } \\
\text { butyrate: } \\
\text { acetoacetate }\end{array}$ \\
\hline & $\mathrm{ml} / \mathrm{kg} / \mathrm{min}$ & $m M$ & & \\
\hline \multicolumn{5}{|l|}{$\begin{array}{l}8 \% \text { Oxygen } \\
\text { breathing }\end{array}$} \\
\hline Saline & $-0.6 \pm 0.3$ & $1.0 \pm 0.3$ & $1.6 \pm 0.4$ & $0.3 \pm 0.1$ \\
\hline Teprotide & $0.6 \pm 0.3$ & $1.0 \pm 0.2$ & $2.1 \pm 0.8$ & $0.5 \pm 0.2$ \\
\hline Saralasin & $-0.2 \pm 0.3$ & $1.7 \pm 0.2$ & $1.8 \pm 0.4$ & $0.3 \pm 0.1$ \\
\hline \multicolumn{5}{|l|}{$\begin{array}{l}5 \% \text { Oxygen } \\
\text { breathing }\end{array}$} \\
\hline Saline & $0.6 \pm 0.4$ & $4.2 \pm 0.8$ & $5.3 \pm 1.5$ & $1.6 \pm 0.5$ \\
\hline Teprotide & $0.3 \pm 0.3$ & $4.2 \pm 0.4$ & $6.0 \pm 0.8$ & $1.5 \pm 0.5$ \\
\hline Saralasin & $-0.5 \pm 0.8$ & $4.3 \pm 0.4$ & $4.6 \pm 0.7$ & $1.5 \pm 0.4$ \\
\hline
\end{tabular}

Values are changes from control values in mean $\pm \mathrm{SE} ; n=7$ in each group. Changes in total body oxygen consumption during hypoxia are not statistically significant, whereas changes in arterial lactate concentration, lactate:pyruvate ratio and $\beta$-hydroxybutyrate:acetoacetate ratio are all significant at $P<0.05$. None of these changes differ among the groups. $\mathrm{kg}$ ) reduced mean aortic blood pressure and total peripheral vascular resistance, and further increased cardiac output and heart rate. Left ventricular $d P / d t$ and $d P / d t / P$, however, were not affected. Left ventricular end-diastolic pressure decreased from $6.1 \pm 1.2$ to $3.9 \pm 1.1$ and $3.3 \pm 1.2 \mathrm{~mm} \mathrm{Hg}$ at 10 and $20 \mathrm{~min}$ of hypoxia. The pressor response to angiotensin I $(1 \mu \mathrm{g})$ was reduced from $21 \pm 1$ to $4 \pm 1 \mathrm{~mm} \mathrm{Hg}(P<0.001)$ after teprotide administration. Fig. 3 also shows that similar administration of normal saline during hypoxia in nine dogs $(12.3 \pm 1.6 \mathrm{~kg})$ did not produce any significant hemodynamic changes. In the latter group, plasma renin activity increased significantly from $1.1 \pm 0.3$ to $5.3 \pm 0.7 \mathrm{ng} / \mathrm{ml}$ per h after $20 \mathrm{~min}$ of hypoxia.

Teprotide was administered to five propranololand phentolamine-pretreated dogs $(13.1 \pm 1.2 \mathrm{~kg})$ that breathed room air. It did not change mean aortic blood pressure (from $97 \pm 7$ to $96 \pm 7 \mathrm{~mm} \mathrm{Hg}$ ), cardiac output (from $2.87 \pm 0.37$ to $2.98 \pm 0.39$ liters $/ \mathrm{min}$ ), left ventricular $d P / d t$ (from $2,874 \pm 106$ to $2,958 \pm 140 \mathrm{~mm} \mathrm{Hg} / \mathrm{s}$ ), and $d P /$ $d t / P$ (from $41 \pm 2$ to $41 \pm 3 \mathrm{~s}^{-1}$ ).

Table VI shows regional blood flows before and after teprotide administration during 5\% oxygen breathing. Teprotide administration increased blood flow to the ventricles and kidneys, while the blood flow to other organs did not change significantly. Concomitantly, organ vascular resistance decreased significantly in the heart, kidneys, stomach, and small and large intestines by $39 \pm 9,36 \pm 3,24 \pm 6,48 \pm 9$, and $41 \pm 6 \%$, respectively. In contrast, neither blood flow nor organ vascular resistance changed significantly after saline administration during hypoxia. Blood flows in the right ventricle, left ventricle, and kidneys were $210 \pm 22,310 \pm 30$, and $531 \pm 33 \mathrm{ml} / 100 \mathrm{~g}$ per min, respectively, before saline administration, and were $218 \pm 25,305 \pm 27$, and $505 \pm 70$ 


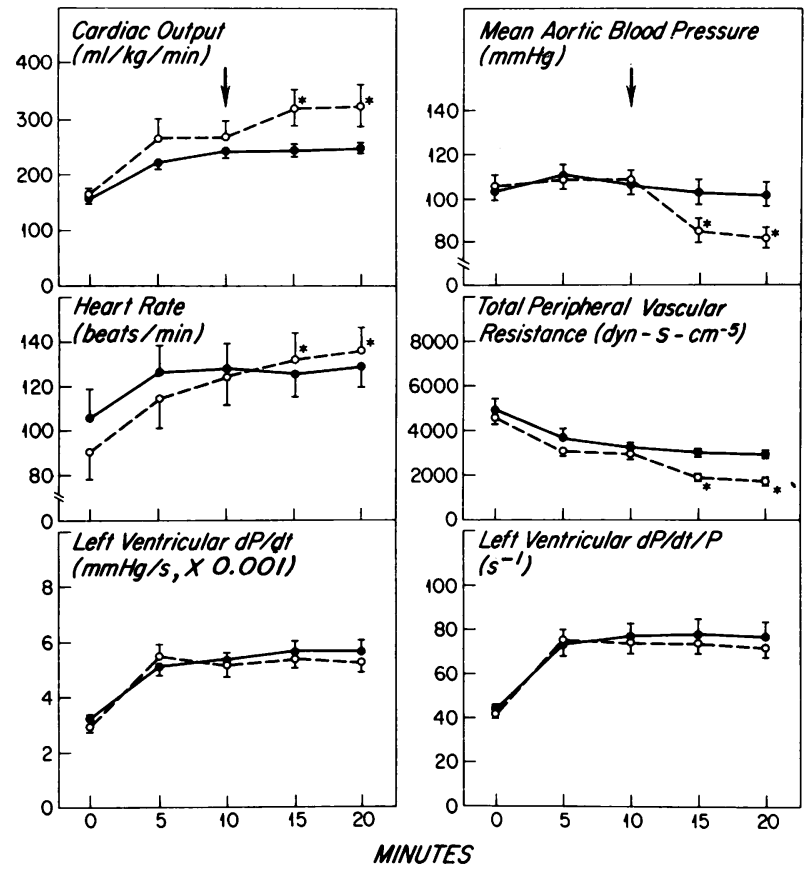

FIGURE 3 Changes in cardiac output, heart rate, mean aortic blood pressure, total peripheral vascular resistance, left ventricular $d P / d t$, and $d P / d t / P$ during $5 \%$ oxygen breathing in two groups of animals that had been pretreated with propranolol and phentolamine. At $10 \mathrm{~min}$ of hypoxia, indicated by arrows, teprotide $(0.5 \mathrm{mg} / \mathrm{kg})$ was administered intravenously to one group of nine dogs (open circles) and normal saline $(2 \mathrm{ml})$ to the other group (closed circles, $n=9)$. Bars show SE. Asterisks indicate values that are statistically different from the averages of values obtained at 5 and $10 \mathrm{~min}$ of hypoxia at $P<0.05$, as determined by Dunnett's test (27).

$\mathrm{ml} / 100 \mathrm{~g}$ per min, respectively, after saline administration.

Effects of teprotide on changes in cardiac metabolism and energetics, and tissue anaerobic metabolism during 5\% oxygen breathing in propranolol- and phentolamine-pretreated dogs. Myocardial oxygen consumption and left ventricular work increased during 5\% oxygen breathing in propranolol- and phentolamine-pretreated dogs (Table VII). These measurements were not affected by either teprotide or normal saline administered at $10 \mathrm{~min}$ of hypoxia, but myocardial oxygen extraction decreased after teprotide administration. Total body oxygen consumption did not change in these animals during hypoxia, nor was it affected by teprotide administration. Furthermore, arterial lactate concentration increased from $2.2 \pm 0.3$ to $6.9 \pm 1.0 \mathrm{mM}$ and lactate:pyruvate ratio from $7.2 \pm 0.8$ to $14.4 \pm 1.2$ during hypoxia in the group that received teprotide. Comparable increases in arterial lactate concentration (from $2.6 \pm 0.4$ to $7.9 \pm 0.8 \mathrm{mM}$ ) and lactate: pyruvate ratio (from $8.9 \pm 1.0$ to $15.6 \pm 1.4$ ) occurred in the group that received normal saline.

\section{DISCUSSION}

Our present study has demonstrated that plasma renin activity increases during acute alveolar hypoxia, and that the renin-angiotensin system inhibition with either teprotide or saralasin significantly reduces the increases in cardiac output, myocardial contractility, mean aortic blood pressure, and heart rate that occur during 5\% oxygen breathing. The changes that occur during $8 \%$ oxygen breathing are not altered significantly. These results suggest that the renin-angiotensin system plays an important role in mediating the hemodynamic responses to severe hypoxia.

In addition to direct vasoconstrictor and cardiac inotropic effects, angiotensin has been shown to stimulate central vasomotor neurons, to increase release of catecholamines from the adrenal medulla, and to potentiate the cardiovascular responses to sympathetic nerve stimulation and administration of sympathomimetic amines (14). This potentiation of adrenergic stimuli by angiotensin probably is attributable to enhanced synthesis and release, as well as to inhibition of neuronal re-uptake, of norepinephrine at sympathetic nerve terminals $(14,28,29)$. The present study shows that the increase in plasma norepinephrine concentra-

TABLE VI

Effects of Teprotide Administration during 5\% Oxygen Breathing on Organ Blood Flows in Five Propranolol- and PhentolaminePretreated Dogs

\begin{tabular}{lcc}
\hline & \multicolumn{2}{c}{$5 \%$ Oxygen breathing } \\
\cline { 2 - 3 } \multicolumn{1}{c}{ Organ } & \multicolumn{2}{c}{ After teprotide } \\
$(0.5 \mathrm{mg} / \mathrm{kg})$
\end{tabular}

Values are mean $\pm \mathrm{SE}$.

* Indicates values that are significantly different from those obtained before teprotide administration at $P<0.05$, as determined by Student's $t$ test for paired comparisons. 
TABLE VII

Effects of Hypoxia and Teprotide on Cardiac Metabolism and Total Body Oxygen Consumption in Dogs Pretreated with Propranolol and Phentolamine

\begin{tabular}{|c|c|c|c|c|}
\hline Group & $\begin{array}{c}\text { Myocardial } \\
\text { oxygen } \\
\text { consumption }\end{array}$ & $\begin{array}{l}\text { Left } \\
\text { ventricular } \\
\text { work }\end{array}$ & $\begin{array}{l}\text { Myocardial } \\
\text { oxygen } \\
\text { extraction }\end{array}$ & $\begin{array}{l}\text { Total body } \\
\text { oxygen } \\
\text { consumption }\end{array}$ \\
\hline & $\mu \mathrm{mol} / 100 \mathrm{~g} / \mathrm{min}$ & $\mathrm{kg} \cdot \mathrm{m} / 100 \mathrm{~g} / \mathrm{min}$ & $\%$ & $\mathrm{ml} / \mathrm{kg} / \mathrm{min}$ \\
\hline \multicolumn{5}{|l|}{ Teprotide $(n=5)$} \\
\hline Control & $496 \pm 45$ & $6.2 \pm 0.5$ & $84 \pm 9$ & $7.5 \pm 0.4$ \\
\hline $5 \% \mathrm{O}_{2}$ & $616 \pm 49^{*}$ & $11.0 \pm 1.4^{*}$ & $90 \pm 6$ & $7.3 \pm 0.4$ \\
\hline $5 \% \mathrm{O}_{2}+$ teprotide & $630 \pm 94^{*}$ & $11.2 \pm 1.3^{*}$ & $76 \pm 4 \ddagger$ & $8.2 \pm 0.5$ \\
\hline \multicolumn{5}{|l|}{ Normal saline $(n=9)$} \\
\hline Control & $509 \pm 40$ & $6.1 \pm 0.4$ & $84 \pm 2$ & $8.1 \pm 0.7$ \\
\hline $5 \% \mathrm{O}_{2}$ & $580 \pm 49 *$ & $10.1 \pm 0.9^{*}$ & $85 \pm 3$ & $7.7 \pm 0.6$ \\
\hline $5 \% \mathrm{O}_{2}+$ saline & $585 \pm 71^{*}$ & $10.2 \pm 1.1^{*}$ & $86 \pm 3$ & $7.0 \pm 0.8$ \\
\hline
\end{tabular}

Values are mean $\pm \mathrm{SE}$.

* Indicates values that are significantly different from the prehypoxic control values at $P<0.05$.

$\ddagger$ Indicates the value that is statistically different from the hypoxic value obtained before teprotide administration at $P<0.05$, as determined by Dunnett's test (27).

tion during severe hypoxia was reduced by teprotide and saralasin. Similarly, saralasin has been shown to reduce the increase in plasma norepinephrine that occurs during strenuous exercise (30). Thus, it appears that endogenous angiotensin may potentiate the effects of sympathetic stimulation that occur physiologically during severe hypoxia and exercise. These results further suggest that the diminished cardiovascular responses to severe hypoxia demonstrated in the present study with teprotide and saralasin infusion could be explained, at least in part, by abolition of the potentiated sympathetic effects.

The direct vasoconstrictor action of angiotensin during hypoxia was documented by a depressor response after teprotide administration in the propranolol- and phentolamine-pretreated dogs. Teprotide also decreased total peripheral vascular resistance, and increased cardiac output and heart rate. Myocardial contractility and left ventricular end-diastolic pressure, however, did not change. The increase in cardiac output after teprotide administration probably was caused, at least in part, by the decrease in aortic blood pressure (31). Teprotide also increased renal and myocardial blood flows. This increase in myocardial blood flow was associated with a decrease in myocardial oxygen extraction; neither myocardial oxygen consumption nor left ventricular work changed significantly. In addition, vascular resistance decreased significantly in the heart, kidneys, and the gastrointestinal tract. These results suggest that angiotensin II exerts an active vasoconstrictor action, especially on the heart, kidneys, and the gastrointestinal tract, during hypoxia, but has no significant effects on myocardial contractility or energetics independent of its effects on the sympathetic nervous system.

The increases in absolute organ blood flows during severe hypoxia were smaller in the teprotide- and saralasin-treated dogs than in the saline-treated controls (Table II). These differences could be attributed, in part, to the differences in cardiac output during hypoxia. When blood flows are recalculated as percents of cardiac output, the differences in blood flow responses among the groups disappear, except for the increase in myocardial blood flow which remains larger in the saline group than in the other two experimental groups. The larger increases in myocardial blood flow and utilization of lactate and pyruvate in the saline group during severe hypoxia probably were related to the higher left ventricular work and myocardial oxygen consumption in that group.

Our study shows that arterial lactate:pyruvate and $\beta$ hydroxybutyrate:acetoacetate ratios increased during both 8 and 5\% oxygen breathing. The increases were larger during $5 \%$ oxygen breathing, indicating a greater degree of anaerobic metabolism during more severe hypoxia. Neither of these ratios, however, was affected by teprotide or saralasin infusion. Total body oxygen consumption also did not change significantly during hypoxia. These results suggest that the diminished cardiac output and blood flow responses to hypoxia in the saralasin- and teprotide-treated dogs did not adversely affect the tissue oxidative metabolism, nor did they exaggerate anaerobic metabolism during $20 \mathrm{~min}$ of hypoxia. The continuing myocardial use of lactate during hypoxia in the teprotide and saralasin groups also indicates that no significant myocardial hypoxia oc- 
curred in these animals. These changes in hemodynamic and metabolic responses to hypoxia also are produced by pretreatment with propranolol (32). The lower concentrations of norepinephrine in the teprotide- and saralasin-treated animals during hypoxia probably produced a smaller calorigenic effect than that in saline-treated dogs, and thus offset the potential effects of the diminished cardiac output or blood flow response on anaerobic metabolism.

Teprotide is known to inhibit kininase II and augment the effects of bradykinin (10). Results of the present study, however, do not allow us to define the role of this bradykinin-potentiating effect of teprotide on the hemodynamic and metabolic responses to hypoxia. Nevertheless, because both teprotide and saralasin produced similar changes, their effects probably are caused primarily by blockade of the reninangiotensin system.

\section{ACKNOWLEDGMENTS}

The authors thank Dr. William B. Hood, Jr., for his helpful criticisms during the preparation of this manuscript. We also thank Andre d'Hemecourt, Charles Scheller, Adele Rymut, Stephanie Arnold, Samuel Rivers, Song Que Lee, Norma Moolten, Deborah Walker, Margaret Bresnahan, and Karen Rose for their technical assistance. The following chemicals were generously supplied by pharmaceutical companies: indocyanine green (Cardio-Green) by Hynson, Westcott \& Dunning, Inc., Baltimore, Md.; teprotide (SQ 20,881) by the E. L. Squibb Institute for Medical Research, Princeton, N. J.; saralasin (P113) by Eaton Laboratories, Div. of MortonNorwich Products Inc., Norwich, N. Y.; phentolamine $\mathrm{HCl}$ (Regitine) by CIBA Pharmaceutical Company, Division of CIBA-GEIGY Corporation, Summit, N. J.; propranolol $\mathrm{HCl}$ (Inderal) by Ayerst Research Laboratories, Montreal, Canada.

This work was supported in part by U. S. Public Health Service grants HL-17403, HL-18318, HL-14646, NO 1 HV 53001, and SO7 RR 05380.

\section{REFERENCES}

1. Robertson, A. L., R. R. Smeby, F. M. Bumpus, and I. H Page. 1966. Production of renin by human juxtaglomerular cells in vitro. Circ. Res. 18/19 (Suppl. I): I-131-I-142.

2. Oliver, W. J., and G. L. Brody. 1965. Effect on prolonged hypoxia upon granularity of renal juxtaglomerular cells. Circ. Res. 16: 83-88.

3. Demopoulos, H. B., B. Highman, P. D. Altland, M. A. Gerving, and G. Kaley. 1965. Effects of high altitude on granular juxtaglomerular cells and their possible role in erythropoietin production. Am. J. Pathol. 46: 497-509.

4. Gould, A. B., and S. A. Goodman, 1970. The effect of hypoxia on the renin-angiotensinogen system. Lab. Invest. 22: 443-447.

5. Tuffley, R. E., D. Rubenstein, J. D. H. Slater, and E. S. Williams. 1970. Serum renin activity during exposure to hypoxia. J. Endocrinol. 48: 497-510.

6. Zakheim, R. M., A. Molteni, L. Mattioli, and M. Park. 1976. Plasma angiotensin II levels in hypoxic and hypovolemic stress in unanesthetized rabbits. J. Appl. Physiol. 41: 462-465.
7. Molteni, A., R. M. Zakheim, K. B. Mullis, and L. Mattioli. 1974. The effect of chronic alveolar hypoxia on lung and serum angiotensin I converting enzyme activity. Proc. Soc. Exp. Biol. Med. 147: 263-265.

8. Spath, J. A., Jr., R. M. Daugherty, Jr., J. B. Scott, and F. J. Haddy. 1971. Effect of acute local renal hypoxia on renin activity in renal venous plasma. Proc. Soc. Exp. Biol. Med. 137: 484-488.

9. Davis, J. O., and R. H. Freeman. 1976. Mechanisms regulating renin release. Physiol. Rev. 56: 1-56.

10. Ondetti, M. A., N. J. Williams, E. F. Sabo, J. Pluščec, E. R. Weaver, and O. Kocy. 1971. Angiotensin-converting enzyme inhibitors from the venom of Bothrops jararaca: isolation, elucidation of structure, and synthesis. Biochemistry. 10: 4033-4039.

11. Pals, D. T., F. D. Mosucci, F. Sipos, and G. S. Denning, Jr. 1971. A specific competitive antagonist of the vascular action of angiotensin II. Circ. Res. 29: 664-672.

12. Gavras, H., and C. Liang. 1978. Redistribution of regional blood flow after inhibition of the angiotensin converting enzyme. Circ. Res. 43: I-59-I-63.

13. Liang, C., H. Gavras, and W. B. Hood, Jr. 1978. Reninangiotensin system inhibition in conscious sodiumdepleted dogs. Effects on systemic and coronary hemodynamics. J. Clin. Invest. 61: 874-883.

14. Reit, E., editor. 1972. Interaction of angiotensin with the autonomic nervous system. Fed. Proc. 35: 1331-1364.

15. Davidson, D. M., J. W. Covell, C. I. Malloch, and J. Ross, Jr. 1974. Factors influencing indices of left ventricular contractility in the conscious dog. Cardiovasc. Res. 8: 299-312.

16. Liang, C. 1977. Metabolic control of circulation. Effects of iodoacetate and fluoroacetate. J. Clin. Invest. 60: 61-69.

17. Rudolph, A. M., and M. A. Heymann. 1967. The circulation of the fetus in utero: Methods for studying distribution of blood flow, cardiac output and organ blood flow. Circ. Res. 21: 163-184.

18. Ramsey, L. H. 1959. Analysis of gas in biological fluids by gas chromatography. Science (Wash. D. C.). 129: 900901.

19. Hickam, J. B., and R. Frayser. 1949. Spectrophotometric determination of blood oxygen. J. Biol. Chem. 180: 457465.

20. Sealey, J. E., J. Gerten-Banes, and J. H. Laragh. 1972. The renin-system: Variations in man measured by radioimmunoassay or bioassay. Kidney Int. 1: 240-253.

21. Henry, D. P., B. J. Starman, D. G. Johnson, and R. H. Williams. 1975. A sensitive radio-enzymatic assay for norepinephrine in tissues and plasma. Life Sci. 16: 375384.

22. Friedland, E. M., and L. S. Dietrich. 1961. A rapid enzymic determination of $\mathrm{L}(+)$-lactic acid. Anal. Biochem. 2: 390-392.

23. Huckabee, W. E. 1956. Control of concentration gradients of pyruvate and lactate across cell membranes in blood. J. Appl. Physiol. 9: 163-170.

24. Williamson, D. H., J. Mellanby, and H. A. Krebs. 1962. Enzymic determination of $\mathrm{D}(-)-\beta$-hydroxybutyric acid and acetoacetic acid in blood. Biochem. J. 82: 90-96.

25. Mellanby, J., and D. H. Williamson. 1974. Acetoacetate. In Methods of Enzymatic Analysis. H. U. Bergmeyer, editor. Academic Press, Inc., New York. 2nd edition. 1840-1843.

26. Winer, B. J. 1971. Statistical Principles in Experimental Design. McGraw-Hill Book Company, New York. 2nd edition. 261-300. 
27. Dunnett, C. W. 1964 . New tables for multiple comparisons with a control. Biometrics. 20: 482-491.

28. McCubbin, J. W. 1974. Peripheral effects of angiotensin on the autonomic nervous system. In Angiotensin, Handbook of Experimental Pharmacology. I. H. Page and F. M. Bumpus, editors. Springer-Verlag New York Inc., New York. 37: 417-423.

29. Bohr, D. F. 1974. Angiotensin on vascular smooth muscle. In Angiotensin, Handbook of Experimental Pharmacology. I. H. Page and F. M. Bumpus, editors. SpringerVerlag New York Inc., New York. 37: 424-440.
30. Fagard, R., A. Amery, T. Reybrouck, P. Lijnen, E. Moerman, M. Bogaert, and A. de Schaepdryver. 1977. Effects of angiotensin antagonism on hemodynamics, renin, and catecholamines during exercise. J. Appl. Physiol. 43: 440-444.

31. From, A. H. L., P. F. Carlyle, L. R. McGregor, M. E. Erickson, and J. N. Cohn. 1977. Effects of vasodilators on determinants of cardiac output in conscious dogs. Circulation. 56: 111-129. (Abstr.)

32. Cain, S. M. 1973. Relative rates of arterial lactate and oxygen deficit accumulation in hypoxic dogs. Am. J. Physiol. 224: 1190-1194. 